UDC 37:355.23

DOI: 10.52534/msu-pp.7(3).2021.39-46

\author{
Maiia S. Serhiienko ${ }^{1^{*}}$, Volodymyr M. Liutyi ${ }^{1}$, Megan Wilson ${ }^{2}$ \\ ${ }^{1}$ National Academy of National Guard of Ukraine \\ 61001, 3 Zakhysnykiv Ukrainy Sq., Kharkiv, Ukraine \\ ${ }^{2}$ Lucian Blaga University of Sibiu \\ 550024, 10 Victoriei Blvd., Sibiu, Romania
}

\title{
Experience in Implementing Distance Learning Technologies in an International Context
}

\section{Article's History: \\ Received: 15.05.2021 \\ Revised: 10.06.2021 \\ Accepted: 22.08.2021 \\ Suggested Citation:}

Serhiienko, M.S., Liutyi, V.M., \& Wilson, M. (2021). Experience in implementing distance learning technologies in an international context. Scientific Bulletin of Mukachevo State University. Series "Pedagogy and Psychology", 7(3), 39-46.

\begin{abstract}
The relevance of the study is determined by socio-cultural processes, which necessitate the revision of methods for organising the educational process, in particular the transition to distance learning, and the establishment of correlations with international standards. The purpose of the article is to identify the features, advantages, and disadvantages of distance learning, along with the prospects for development in accordance with the comparative analysis of Ukrainian and foreign experience with distance education. Methods and techniques varied depending on the tasks at each research stage, thus, the method of a targeted selection, the comparative method, the generalisation and systematisation of the theoretical material, and others were applied. The article substantiates the prospects for the development and implementation of distance learning technologies. The Ukrainian and foreign studies which focus on the "distance education" are analysed; ways of the distance learning implementation are outlined; the conditions for the appropriate and effective distance learning introduction are indicated; advantages and disadvantages of the distance learning are identified, the urgency of the development of distance education in Ukraine is substantiated. The factors that contributed to the emergence and development of distance learning courses are highlighted, the current problems of introduction of distance learning technologies are specified. The article compares the experience of introducing distance learning in different countries, which is based on statistics for 2020-2021. It is stated that the student of the distance learning course must have great will and motivation, be able to properly organise their time, since distance learning is directly aimed at self-education and self-development of the learner. The practical value of the obtained results lies in the application of distance technologies in the educational activities of higher education institutions and in accelerating the modernisation and adaptation of the current education system in Ukraine, in accordance with the requirements and trends of the global education sphere
\end{abstract}

Keywords: distance learning, e-learning, self-education, pedagogical learning technologies, educational technologies

\section{INTRODUCTION}

Trends in the development of education in the international arena and the latest challenges allow discussing the prospects and relevance of the development of such areas of education as distance learning. Modern requirements for a professional in any field stimulate specialists to constantly develop their skills and abilities, expand the scope of knowledge to be able to compete in the labour market. Continuous training and self-development of specialists or future specialists should be inseparable from work or daily activities, should be as convenient and effective as possible, should meet all the needs and bring education applicants closer to the final result. For its part, the COVID-19 pandemic 
confirmed the importance of distance learning and enabled humanity to reevaluate the need for high-quality education in any case and challenged researchers to identify new ways to develop and introduce distance learning technologies in the modern educational process.

Notably, the use of innovative technologies to improve the educational process is one of the priority areas of the state policy of Ukraine, which is reflected in the Concept of development of the digital economy and Society of Ukraine for 2018-2020 [1]. There is an increase in the interest of Ukrainian researchers in this field of pedagogy. There are new studies by O.V. Bazeliuk [2] and V.M. Kukharenko [3], who are working on the development of a digital culture among teachers, searching means to create and introduce new models of learning. Their studies are devoted to ways to use cloud technologies, technical means, and internet platforms during the introduction of blended and distance learning models $[2 ; 3]$. The researchers emphasise the positive result of using Internet resources and creating online courses, work on the development of the digital culture among teachers $[2 ; 3]$. It is necessary to outline the contribution to the Ukrainian education of B.I. Shunevych $[4 ; 5]$, S.P. Shumaieva [6], O.I. Ohiienko [7], who help to more actively modernise the education system of Ukraine to European standards by analysing the experience of introducing the latest educational technologies into the educational process in foreign leading educational institutions.

It is also important to note the growing rate of introduction of distance education by universities in different countries. During the pandemic, almost all educational institutions were required to create distance learning courses. This trend bypassed educational institutions that already had the necessary base and were able to continue or easily switch to the desired teaching style. Teachers and researchers began to adapt faster to the new conditions and began to search for ways to provide high-quality education to future specialists. The main requirement was to maintain the highest possible level of training educational applicants in the new conditions and release specialists who will immediately be able to perform their duties. In this context, it is advisable to add that the research and teaching staff could immediately test all the pros and cons of distance learning, adjust and transform their professional activities, and quickly respond to new challenges since all segments of professional growth and professional development of teachers switched to online platforms as well. The above has had a positive impact on teachers' acquisition of new skills, expanded their horizons, and helped research and teaching staff to quickly respond to the needs of educational applicants in new teaching conditions, correctly and quickly adjust the educational process and remain a competitive specialist.

It should be noted that distance learning offers new prospects for the development of self-education of applicants for education. Such organisation of the learning process is based on increasing the student's motivation, encourages educational applicants to independently search, analyse, systematise and generalise training materials, promotes self-organisation and self-control. Therefore, the rapid development of distance learning at the world level and the need for further research on improving distance education substantiate the relevance of the chosen issue.

The purpose of the article is to identify the features, development prospects, advantages, and disadvantages of distance learning technologies based on a comparison of Ukrainian and foreign experience in obtaining distance education. In accordance with the purpose, the main tasks are: 1) based on the analysis of scientific literature, clarify the essence of "distance learning"; 2) distinguish "extramural education" and "distance learning"; 3) identify the advantages and disadvantages of distance education; 4) characterise the differences in the development of distance education in Ukraine and abroad.

\section{LITERATURE REVIEW}

The modern educational space is characterised by a change in the development area of pedagogy, in the essence and content of educational activities, as a result of which a qualitatively new information structure appears, and the educational trajectory is planned with an emphasis on global trends, intelligence, information and communication technologies of training, etc. In particular, this applies to Ukraine, where the education system is being modernised, there is a shift from focusing solely on "standard learning", the development and implementation of blended and distance learning models, the creation and implementation of information and educational environment, the systematisation of pedagogical tools, the establishment of training courses and programmes based on the use of internet platforms during online education, etc.

In general, Ukrainian researchers who devoted their studies to distance education and the search for an exhaustive definition of the phenomenon are V.M. Kukharenko (analysis and research of the prospects of distance education, the creation of a course for developing and ensuring the functioning of distance learning courses on the MOODLE platform for teachers) [3], V.V. Bondarenko (theoretical and methodological studies on the implementation of the educational process in quarantine) [3], V.E. Luniachek (monitoring the development of higher education and distance learning in Ukraine and abroad) [8], I.H. Bloshchynskyi (the essence and content of distance education: theory and practice) [9], and others. Ukrainian researchers conducted a number of studies of the main foreign centres of distance learning, the experience of introducing distance education in the educational process, prospects, strengths, and weaknesses of distance education, and thereby oriented and accelerated the corresponding process in Ukraine $[3 ; 8 ; 9]$. However, despite a large number of studies, modern distance education in Ukraine resembles conventional forms of distance learning, without applying all the possibilities of fundamentally new forms, which necessitates defining the given categories. Thus, the Regulation on distance learning defines it as an individualised process of acquiring knowledge, 
skills, and abilities [10]. The document notes that the learning process is based on the introduction of modern psychological and pedagogical models and the use of information and communication technologies, while the participants in the educational process are remote from each other [10].

In the pedagogical environment, it is believed that M. Thompson, M. Moore, A. Clark and D. Keegan, independently of each other, shaped the definition of "distance learning" [11]. Each of these authors emphasised a separate aspect of this method, except for the researcher D. Keegan, who tried to combine most of the definitions and establish the characteristics of distance learning based on them [11] Having examined the experience of introducing distance learning in the leading countries of the world, it became clear this model of learning is developing quite actively, and the issue of distance learning is still relevant among foreign reseachers, for example, Professor J. Taylor quite actively studied the classification of distance learning models at different levels of learning forms (especially at the level of types of educational materials and ways of their correspondence between teacher and student) [12]. The Professor's research on five models of distance learning is considered quite valid for the chosen issue and is frequently cited. Modern research on distance education, tools, trends, areas, statistics of the use of distance learning models are also included on the official websites of leading higher educational institutions. In particular, attention was drawn to the experience of such foreign universities as the University of Kansas (USA) [13], the University of Newcastle (Australia) [14], the National Center for Distance Education CNED (France) [15], The Open University (Great Britain) [16], Queen's University (Canada) [17].

Notably, over the past few years, there has been a growing interest in online training not only for educational applicants but also for teachers. Thus, M. Kearney and D. Maher [18] investigated the effectiveness of using mobile devices in teacher training. Taking into account the results obtained, researchers depict the methodology, prove its effectiveness, and indicate that the practical use of mobile devices is an effective approach to the professional growth of teachers [18]. C.D. Lay, B. Allman, R. Cutri, and R. Kimmons [19] have been conducting research on online teacher development for decades. In the "Study of research over the past ten years in the field of teacher training on the Internet", they summarise scientific achievements that confirm the growing popularity of ways to ensure high-quality training of teachers through online learning, nevertheless, it is noted that the development of distance learning is ahead of thorough empirical research [19]. The article draws attention to the variability of needs and requirements for online training programmes, indicates the feasibility of further research for more effective training of teachers, and therefore the development of distance education in general [19].

Thus, despite numerous studies that focus on "distance learning", the issue is understudied due to the constant improvement of pedagogical technologies and educational materials, the rapid development of Internet resources, means and methods of communication, which allows emphasising the relevance of further searches in the chosen area.

\section{MATERIALS AND METHODS}

The theoretical and methodological basis of the article is 21 studies, 4 regulatory documents and laws of Ukraine on education. The search for scientific literature focused on studies that covered "distance learning", "online learning", "correspondence education training", "e-learning", "extramural learning", "Case technologies" in the context of the pedagogical sphere. Preference was given to scientific sources for 2018-2021, however, the study used sources of an earlier publication, the interest in which was due to the fundamental importance of the results of these studies.

Work on the stated issue began with determining the research focus, purposes, tasks, article structure, sample bases, and characteristics of the research material, selection of statistical information, research methods. Methods and techniques of research varied depending on the tasks of each stage, so the method of a targeted selection of necessary information was used, a theoretical and comparative analysis was conducted, generalisation and systematisation of scientific and pedagogical sources were applied, which helped to determine the issue development level, clarify the essence of "distance learning", distinguish "extramural education" and "distance learning", identify the advantages and disadvantages of distance education. To substantiate certain pedagogical conditions for the introduction of distance education in Ukraine, an analysis of the regulatory framework and guidelines was conducted.

Special attention was paid to scientific sources that published statistics on the introduction and use of distance learning technologies in different countries for the period 2020-2021. Statistics were monitored both in Ukraine and abroad, in order to compare the experience of the criteria of confidence in distance learning, the intensity of development, the regular use of distance education models in different countries. A number of distance learning systems were discovered that allow providing a high level of distance learning, and platforms that are most popular among foreign applicants for education and Ukrainians were identified. The comparative method characterised the differences in the development of distance education in Ukraine and abroad, methods of systematic analysis and generalisation made it possible to order the results and conclusions of the study, highlighting the prospects for further research aimed at obtaining new scientific results.

\section{RESULTS AND DISCUSSION}

\section{General characteristics of distance learning}

First, it is necessary to define "distance learning" within this study. It is worth noting that currently there is no single definition of this phenomenon, moreover, the interpretation differs in relation to the scientific achievements of different researchers and depending on the origin of scientific 
achievements. Along with "distance learning" or "distance education", the research can also use "open education", "e-education", "virtual learning" or "tele-learning". Foreign researchers use several terms, for example, e-learning, distance learning, education at a distance, distance teaching, distance education, on-line learning, open learning, open and distance learning, and so on, which indicates their versatility and ambiguity.

Notably, extramural and distance learning can be equated. However, the authors consider this completely erroneous, since despite numerous common characteristics, for example, the geographical distance between the teacher and the applicant for education, a certain amount of material, the use of information technologies, etc., it is worth highlighting some differences. The main differences include:

1) obtaining distance education provides for a comfortable environment for each student and the opportunity to study on-the-job, constant communication (if necessary) between the student and the teacher, does not require a physical presence in the educational institution;

2) distance education allows the future specialist to independently choose the sequence of studying subjects and independently adjust the time frame for processing materials;

3) during extramural learning, the deadlines for completing certain academic work (tests, exams, etc.) are clearly defined and have deadlines; during distance learning, the deadlines can be adjusted at the request of applicants for education;

4) during extramural education, students communicate with teachers only during classroom studies, where students can ask questions and get advice from the teacher on complex issues, while distance education is aimed at constant communication between the teacher and applicants for education;

5) distance education, unlike extramural, is aimed at an individual approach to each applicant of education, and so on.

An important factor and difference between extramural and distance education is the ability (when receiving distance education) to organise a group study of the material, an online meeting to discuss important or incomprehensible issues, and perform a joint project at any convenient time. Thus, when receiving distance education, there is more frequent communication and cooperation not only between the student and teachers but also among applicants for education. Therewith, the importance of distinguishing distance and extramural learning is addressed by A.V. Ovcharuk [20], noting that the Ukrainian researcher B.I. Shunevych $[4 ; 5]$ is of the opinion that the terms "distance learning", "open education", "electronic education", "virtual learning" are equivalents since they have common features and characteristics. For her part, A.V. Ovcharuk [20] claims that distance education and distance learning should be considered precisely in the context of global education since it is primarily associated with the construction of a new educational technology that provides for the use of new learning tools, namely computers, information networks, the global internet system, and the necessary skills and competencies for its use. Quite accurate is the view of G.V. Datsenko and Z.V. Suzanska [21] in "Distance learning as a means of stimulating self-education", they indicate that "distance learning is considered by researchers as a form of education organisation when students are remote from the teacher in space and time but can maintain a dialogue through means of communication. The provision of access to training materials and recommendations for working with them takes place in a convenient place and at a convenient time. This makes it possible to reduce the number of classroom studies and save time for more active independent work, to ensure individualisation of training" [21, p. 17].

Upon examining the foreign studies on distance learning, it can be noted that "distance learning" can be used in a broad and narrow sense. In a broad sense, different forms of training are implied. In this case, the term is synonymous with "correspondence education", "self-study", "TV training", and the like. In a narrow sense, "distance education" is interpreted as an educational process implemented through modern information technologies, while the teacher and the applicant of education are physically distant from each other. It is important to highlight several interpretations of "distance learning" by A.A. Akhanyan, which are mentioned by O.I. Ohiienko [7] in "Distance pedagogical education: foreign and national experience":

1) "... new organisation of the educational process, which is based on the principle of independent student learning;

2) ... a set of information technologies that ensure the delivery of the main scope of material to students;

3) ... a new extramural learning degree, where

4) the use of information technologies is provided" [7].

For his part, the Swedish educator B. Holmberg identified several main characteristics of distance education (Fig. 1).
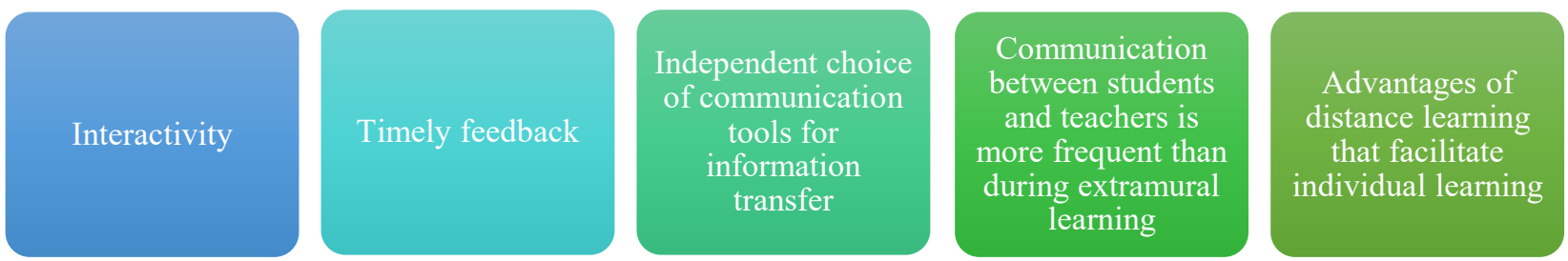

Figure 1. The main characteristics of distance education according to B. Holmberg

Analysis of the monograph edited by V.M. Kukharenko, V.V. Bondarenko [3], research by I.H. Bloshchynskyi [9], V.E. Luniachek [8], O.V. Bazeliuk [2], J. Taylor [12], the development concepts of distance education in Ukraine [22] make it possible to note that, despite the ambiguity of "distance learning", it is characterised by such aspects (Fig. 2). 

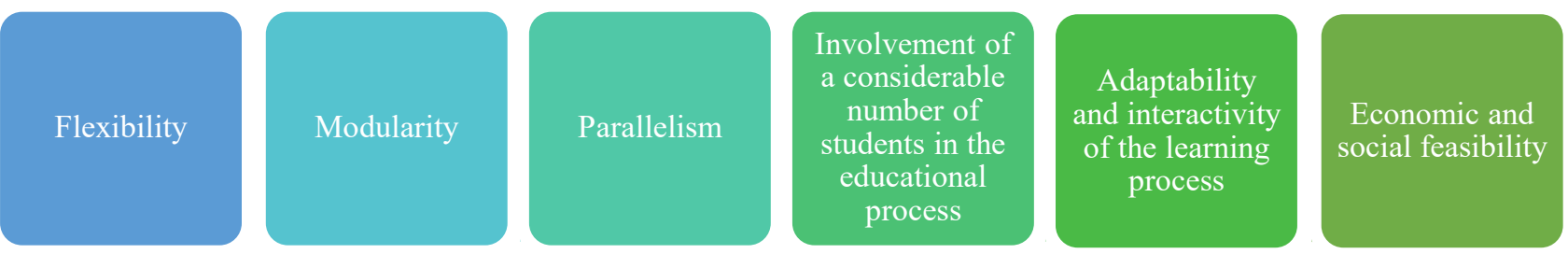

Figure 2. Characteristics of distance learning in accordance with the views of Ukrainian and foreign scientists

In "Fundamentals of higher school pedagogy", V. Luniachek [8, p. 114], based on the research by A. Melnikov,

identifies four general models of distance learning implementation (Table 1):

Table 1. General models for implementing distance learning according to V. Luniachek

This model resembles an extramural learning scheme. The main differences are
that special educational and methodological complexes of teaching tools are developed
and used, and more free time frames for the beginning and end of the educational
process are provided

Correspondence education

This model is based on a constant exchange of educational materials, completed tasks, recommendations, and so on by mail (or in some other way) between the teacher and the student

To deliver educational and methodical information, television, radio, etc., are

Radio and television model used in classes. Consultations, exams, and other organisational forms of classes are implemented in person

Internet technologies

This model is based on the use of the Internet

It is also worth mentioning the new role of the teacher and greater freedom of action of educational applicants along with which high-quality training of future specialists should remain at the appropriate level. The rapid development of distance education is caused by:

1) the need for high-quality education accessible to every citizen;

2) the need of educational applicants for mobility and parallelism of processes;

3) the need to search for new and effective forms of learning, the use of information and communication technologies in the classroom;

4) the socio-economic basis for the introduction of distance education, the need for the fulfilment of each segment of society, and the search for ways to save money.

5) development and content specifics of the educational concept in society, etc.

Educational organisations that implement distance learning are divided into distance schools and higher schools, conventional universities, and electronic platforms for obtaining distance learning. Over the past decade, so-called academic and corporate virtual educational organisations have been actively created and developed all over the world, they do not have separate premises like conventional educational institutions which makes it possible to considerably reduce the financial costs of such an institution, since there is no need to maintain classrooms, offices or student dormitories. Students are trained in such virtual learning segments through the use of a global or corporate Internet [23]. Moreover, to be competitive in the current environment of changing education systems, most of the world's leading universities and schools are attempting to introduce elements or courses of distance education. This allows representatives of different countries and nations to obtain a high-quality education without leaving their homes, raises the rating and level of confidence in the educational organisation, and popularises the educational institution.

\section{Experience in implementing distance learning: An international context}

Statistical data $[24 ; 25 ; 26]$ and research by O.M. Kashuba [27] allow noting that among European countries, distance learning has received the greatest development in France, Ireland, Finland, Norway, Switzerland, and the United Kingdom. Quite considerable results of the development of distance education in France can be observed in the National Center for Distance Education CNED [15]. At present, the education in this centre is received not only by students or adults but also by schoolchildren who additionally study subjects or prepare for academic competitions. Universities and colleges in the UK have been rapidly developing distance education in recent years and offer a wide range of distance learning courses. The so-called "e-education" in the UK is more aimed at improving the skills of specialists who have work experience and need further professional growth. Frequently, such distance education is funded not only by the state but also has commercial contributions. It is believed that the first electronic distance course of the Open University of Great Britain served as a well-known impetus for the development of modern distance education [16], the results of which received positive ratings. Later, similar training courses began to appear in the USA, Canada, Austria, Spain, Turkey, India, etc. It is worth noting the positive results of the development and provision of distance learning in 
Canada, Iceland, Finland, and Norway. This is due not only to a satisfactory level of education systems in these countries but also to more stringent geographical conditions. Therefore, Canada is currently among the leaders in the development of e-learning and software for distance education, one of the leading universities developing in this area is the Research Public University "Queen's" [17]. According to the research, distance education in the United States is also in high demand. This trend can be explained by the Internet availability in school institutions, the high level of computerisation of the population, and a developed communication and telecommunications systems, which are the basic provisions for the successful implementation of distance education. The goal of educational institutions is not only to provide high-quality training for their applicants but also to quickly train, retrain, or improve the skills of personnel in the chosen highly specialised area. Published statistics make it possible to note that public educational institutions quite frequently offer to master various academic programmes remotely and get a bachelor's degree, which makes distance education in the United States quite attractive for young people $[24 ; 25 ; 28]$.

As for the Asia-Pacific region, Australia, Japan, China, and Korea outstand notably. Thus, in Japan, the absence of a state accreditation system for educational institutions is one of the most important issues, and distance learning is considered an integral part of the self-development of every citizen [28]. It should be noted that distance education is developing quite rapidly in countries that are "economically weak". The model of obtaining an education at a distance and at a convenient time, accessing educational materials 24 hours a day, and the ability to test knowledge gradually made it possible to obtain higher education for the world's poor population. There are a number of free platforms that offer courses of various types. The most popular on the world stage are Coursera (more than 10 million users), $E d X$ (more than 34 million users), Udacity (more than 1.6 million users) [24], etc. Although the courses are free, the user must pay for the certificate. In this way, companies cover part of their expenses.

Upon comparing the regulatory framework of different countries, it can be concluded that "foreign higher education institutions independently develop regulations on the organisation of distance learning for bachelors, masters, and, recently, doctoral students, in compliance with certain rules for its implementation at the full-time level, while state bodies propose amendments to the organisation of distance learning, and in the countries of the former Soviet Union, the organisation is centralised by state bodies in the form of resolutions, decrees, etc." [4]. In Ukraine, the introduction of distance learning takes place based on state educational institutions and state laws, including:

1. The Constitution Of Ukraine [29].

2. Law of Ukraine "On Education" [30].

3. The Concept of Development of the Digital Economy and Society of Ukraine for 2018-2020 [1].

4. Order of the Ministry of Education and Science of
Ukraine No. 466 "The Regulations on Distance Learning” dated 25.04.2013 [10].

Free platforms for massive online courses have started being launched in Ukraine. The most famous of them is the public project of massive open online courses Prometheus. Several free social projects were also designed, for example, courses for greater education of Ukrainian citizens on the platform Diia. Digital education, a special project for free learning of English by Ukrainians Lingva skills. Among teachers, such platforms and studios of online education as EdEra, NaUrok, and Vseosvita are popular, yet, although access to the materials is free, obtaining a certificate takes place on a paid basis. On the grounds of statistical data [31] and the Ukrainian theoretical background $[2 ; 3 ; 5]$, the most common distance education platforms in Ukraine are Moodle, A tutor, Dokeos.com, Talent LMS, Litmos, eFront, and others. For conducting tests and controls: Google Classroom, Kahoot, Learningapps, and so on.

Notably, there is a growing motivation of educational applicants in Ukraine. Students ground their desire to learn primarily by the need for professional growth, not simply to achieve an academic goal. To increase the student's motivation during distance learning, the teacher should think through the structure and material of the course in advance, substantiate the use of the selected tools. An important role in distance education is assigned to communicative interaction between applicants for higher education and the teacher. It is necessary to introduce creative tasks and projects, provide comprehensive support to students, give timely feedback on the results of the applicant's work, and comprehensively stimulate interest in the subject using modern teaching methods and technologies. All of the above requires additional time from the teacher, which should also be governed and supported by regulatory documents.

Therefore, distance learning in Ukraine, comparing with other countries, has recently begun to develop rapidly. Many higher educations institutions started using distance education technologies only after the introduction of quarantine measures in 2020, and they continue to work actively in this area today. At present, there are many requirements for teachers who need to adapt to a new model of education and master new teaching technologies. The prospects for further scientific developments will become quite impactful for the education system of Ukraine, will facilitate and improve the quality of education, increase the level of motivation during distance learning, and will contribute to the study of the communicative component of the educational process in remote conditions.

\section{CONCLUSIONS}

Thus, having studied "distance learning", its characteristics and ways of implementation, it can be noted that distance education is primarily training according to an individual plan, which makes getting an education comfortable for the applicant since the student will receive constant and comprehensive support from the teacher without personally visiting the educational institution. This characteristic is 
the main difference between obtaining distance and extramural education.

The study discovered that similarly to other forms of education, distance education has a number of advantages and disadvantages. The advantages include mobility, concurrency, flexibility, interactivity, a strong motivational component of educational applicants, lower economic costs compared to the costs of classical educational institutions, saving time for teachers and educational applicants, constant communication with the teacher, help in studying subjects, the ability to manage the course time frame, and so on. Nevertheless, there is a number of disadvantages, for example, the insufficient number of classroom studies. This also includes the issues of conducting final tests, since, in contrast to full-time or extramural training, distance learning does not involve conducting final tests or exams, the final score is displayed based on the results of each module.

Comparing the experience of implementing distance learning in the leading countries of the world and Ukraine, it is impossible not to notice a considerable gap. However, a great number of countries have been developing distance education for several decades, while Ukraine has recently started exploring this area. There are noticeable changes in this area at the state level, the main proof of this is the creation of free online courses and platforms. The authors of the study are certain that state institutions of higher education should take more initiative in creating an e-learning base, focusing on the needs, specialisations, and interests of educational applicants.

\section{REFERENCES}

[1] Resolution of the Cabinet of Ministers of Ukraine No. 67-p "On Approval of the Concept of Development of the Digital Economy and Society of Ukraine for 2018-2020 and Approval of the Action Plan for Its Implementation”. (2018, January). Retrieved from https://zakon.rada.gov.ua/laws/show/67-2018-\%D1\%80/ed20180117\#Text.

[2] Bazeliuk, O. (2020). Organizational and pedagogical conditions of development of digital culture of pedagogical employees. Professional Pedagogics, 2(21), 21-28.

[3] Kukharenko, V.M., \& Bondarenko, V.V. (Eds.). (2020). Emergency distance learning in Ukraine. Kharkiv: Miska drukarnia.

[4] Shunevych, B.I. (2008). Tendencies of distance learning development at foreign higher schools. Information Technologies and Learning Tools, 7(3). Retrieved from https://journal.iitta.gov.ua/index.php/itlt/article/view/122/108.

[5] Shunevych, B.I., \& Rak, N. (2019). Prospects of applying the massive open online courses at the Ukrainian institutions of higher education. Visnyk of Lviv University. Series Pedagogics, 34, 271-278.

[6] Shumaieva, S.P. (2011). Trends of distance learning of foreign languages developing in secondary and higher education in America and leading European countries. Retrieved from http://lnnk.in/gAbq.

[7] Ohiienko, O.I. (2012). Distance pedagogical education: Foreign and native experience. Kyiv: Ivan Zyazyun Institute of Pedagogical and Adult Education of the National Academy of Educational Sciences of Ukraine.

[8] Luniachek, V.E. (2014). Fundamentals of higher school pedagogy. Kharkiv: V.N. Karazin Kharkiv National University.

[9] Bloshchynskyi, I. (2015). Essence and content of the notion "distance learning" in foreign and national scientific literature. Bulletin of the National Academy of the State Border Guard Service of Ukraine. Series: Pedagogy, (3). Retrieved from https://nadpsu.edu.ua/wp-content/uploads/2018/10/visnik_3_2015_pdn.pdf.

[10] Order of the Ministry of Education and Science of Ukraine No. 466 "On Approval of the Regulations on Distance Learning”. (2013, April). Retrieved from https://zakon.rada.gov.ua/laws/show/z0703-13/ed20130425\#Text.

[11] Sinyavina, Yu.V., \& Protsenko, N.M. (2013). The introduction of distance learning at the university on the basis of the system Moodle. The Bulletin of the Kharkiv National Agricultural University of V.V. Dokuchaeva. Economic Sciences Series, 8, 148-156.

[12] Taylor, J. (2001). Fifth generation distance education. Higher Education Series. Report 40. Retrieved from http://www.c3l.uni-oldenburg.de/cde/media/readings/taylor01.pdf

[13] Official website of the University of Kansas School of Education and Human Sciences. (n.d.). Retrieved from https://educationonline.ku.edu/community/distance-education-evolution-in-2020.

[14] Official website of the University of Newcastle. (n.d.). Retrieved from https://www.newcastle.edu.au/?utm source=studyportal\&utm_medium =edm\&utm_campaign=programmes-2020-cm-int\&utm_term=generic\&utm_ content $=\mathrm{b}$-arts.

[15] Official website of the CNED. (n.d.). Retrieved from https://www.cned.fr/.

[16] Official website of the Open University of Great Britain. (n.d.). Retrieved from https://www.openuniversity.edu/courses.

[17] Official website of the Queen's University at Kingston. (n.d.). Retrieved from https://www.queensu.ca.

[18] Kearney, M., \& Maher, D. (2019). Mobile learning in pre-service teacher education: Examining the use of professional learning networks. Australasian Journal of Educational Technology, 35(1), 135-148.

[19] Lay, C.D., Allman, B., Cutri, R.M., \& Kimmons, R. (2020). Examining a decade of research in online teacher professional development. Retrieved from https://www.frontiersin.org/articles/10.3389/feduc.2020.573129/full.

[20] Ovcharuk, O.V. (2006). Conceptual approaches to the open education technologies application and dictance learning in abroad and its role in the education modernization processes. Information Technologies and Learning Tools, 1(1). Retrieved from https://journal.iitta.gov.ua/index.php/itlt/article/view/292/278. 
[21] Datsenko, H.V., \& Suzanska, Z.V. (2017). Distance learning as a means of stimulating self-education. In L.B. Lishchynska (Ed.), Distance learning as a modern educational technology (pp. 17-20). Vinnytsia: VITE KNUTE.

[22] The concept of distance education development in Ukraine. (2000). Retrieved from http://uiite.kpi.ua/2019/06/03/1598/.

[23] Analysis of the dissemination of distance learning in the world. (2020). Retrieved from https://buklib.net/books/24202/.

[24] 100+ must know online learning statistics in 2021. (2021). Retrieved from https://www.guru99.com/online-learningstatistics.html.

[25] 50 online education statistics: 2020/2021 data on higher learning \& corporate training. (2020). Retrieved from https://research.com/education/online-education-statistics.

[26] Distance learning statistics and growth of online education in 2020. (2020). Retrieved from https://blog.otter.ai/distancelearning-statistics/.

[27] Kashuba, O.M. (2011). Foreign experience of the system of continuing education implementing and prospects of its realization in Ukraine. Investytsiyi: Praktyka ta Dosvid, 10, 43-48.

[28] Aoki, K. (2012). Generations of distance education: Technologies, pedagogies, and organizations. Procedia. Social and Behavioral Sciences, 55, 1183-1187.

[29] The Constitution of Ukraine. (1996, June). Retrieved from https://zakon.rada.gov.ua/laws/show/254\%D0\%BA/96\%D0\%B2\%D1\%80\#Text.

[30] Law of Ukraine No. 2145-VIII “On Education”. (2017, September). Retrieved from https://zakon.rada.gov.ua/laws/ show/2145-19\#Text.

[31] Research of the distance learning implementation in Ukraine (March-April 2020). (2020). Retrieved from https://nus.org. ua/wp-content/uploads/2020/05/Research2020_ProSvit_MF1.pdf.

\title{
Майя Станіславівна Сергієнко ${ }^{1}$, Володимир Миколайович Лютий'ㅗ Меган Вілсон ${ }^{2}$
}

${ }^{1}$ Національна академія Національної гвардії України

61001, майдан Захисників України, 3, м. Харків, Україна

${ }^{2}$ Університет Сібіу імені Лучіана Блага

550024, 6-р Вікторії, 10, м. Сібіу, Румунія

\section{Досвід впровадження технологій дистанційного навчання у міжнародному контексті}

\begin{abstract}
Анотація. Актуальність дослідження визначається соціокультурними процесами, що зумовлюють потребу в перегляді методів організації освітнього процесу, зокрема перехід на дистанційне навчання, та встановленні корелятивних зв’язків із міжнародними стандартами. Метою статті є виявлення особливостей, переваг і недоліків дистанційного навчання, а також перспектив розвитку відповідно до порівняльного аналізу українського та закордонного досвіду отримання дистанційної освіти. Методи та прийоми роботи варіювалися залежно від завдань на кожному етапі дослідження, зокрема використовувалися: метод цілеспрямованої вибірки, зіставний метод, метод узагальнення та систематизації теоретичного матеріалу тощо. У статті обгрунтовано перспективність розвитку та впровадження технологій дистанційного навчання. Проаналізовано роботи українських і зарубіжних вчених, які досліджували поняття «дистанційна освіта», описано шляхи реалізації дистанційного навчання, окреслено ситуації, за яких запровадження дистанційної освіти є доречним та ефективним, з'ясовано переваги та недоліки дистанційних технологій, обгрунтовано актуальність розвитку дистанційної освіти в Україні. Виокремлено чинники, які сприяли появі та розробці дистанційних курсів, а також конкретизовано сучасні проблеми впровадження дистанційних технологій. У роботі порівнюється досвід запровадження дистанційного навчання в різних країнах світу, який базується на статистичних даних за 2020-2021 роки. Вказано, що слухач курсу дистанційного навчання має володіти великою силою волі, мати значну мотивацію, вміти правильно організовувати свій час, адже дистанційне навчання, безпосередньо, направлене на самоосвіту й саморозвиток здобувача освіти. Практичне значення отриманих результатів полягає у застосуванні дистанційних технологій в освітній діяльності закладів вищої освіти та у прискоренні процесу модернізації й адаптації чинної системи освіти в Україні, відповідно до вимог і тенденцій глобальної освітньої сфери
\end{abstract}

Ключові слова: дистанційна освіта, електронна освіта, самоосвіта, педагогічні технології, технології навчання 